\title{
Studies on $\beta$-Glucanases
}

\author{
SOME PROPERTIES OF A BACTERIAL ENDO- $\beta-(1 \rightarrow 3)$-GLUCANASE SYSTEM
}

\author{
By DAVID J. MANNERS and GLYNN WILSON \\ Department of Brewing and Biological Sciences, Heriot-Watt University, \\ Edinburgh EH1 $1 H X$, U.K.
}

(Received 29 January 1973)

\begin{abstract}
A commercial enzyme preparation, originally obtained froma Flavobacterium (Cytophaga), was fractionated by continuous electrophoresis, giving a protein fraction which hydrolysed laminarin, carboxymethylpachyman, barley $\beta$-glucan, lichenin and cellodextrin in random fashion. This enzymic activity was not very stable. Ion-exchange chromatography and molecular-sieve chromatography on Bio-Gel P-60 showed that this activity was due to two specific $\beta$-glucanases, an endo- $\beta-(1 \rightarrow 3)$-glucanase and an endo- $\beta-(1 \rightarrow 4)$-glucanase. The two enzymes occur in both high- and low-molecular-weight forms, the latter endo- $\beta$ $(1 \rightarrow 3)$-glucanase having a molecular weight of about 16000 .
\end{abstract}

For some years, we have been interested in enzymic methods for the structural analysis of polysaccharides. As part of these studies, the action of a bacterial 'laminarinase' preparation on yeast $\beta$-glucan and on laminarin has been examined (Manners \& Patterson, 1966; Fleming et al., 1967). Enzyme action resulted in the selective hydrolysis of some $\beta-(1 \rightarrow 3)$-glucosidic linkages, but $\beta-(1 \rightarrow 6)$-glucosidic linkages were not attacked. For this type of work, it is essential that the specificity of the enzyme be defined in an unambiguous manner. We now describe the partial purification and some properties of the laminarinase preparation. A preliminary account of these results has been given elsewhere (Manners \& Wilson, 1972).

\section{Methods and Materials \\ Analytical methods}

Reducing sugars were determined by a modified Nelson method (Robyt \& Whelan, 1968), the reagents being calibrated against glucose. This method is more satisfactory than other modifications (Somogyi, 1945, 1952) of the original Nelson (1944) method, which are affected by low concentrations of salts or buffers. Protein was determined by a modified Lowry method (Miller, 1959), calibrated against bovine serum albumin. The protein content of column fractions was determined from the extinction at $280 \mathrm{~nm}$.

\section{Separation methods}

Descending paper chromatography was carried out on Whatman no. 1 paper by using ethyl acetatepyridine-water $(10: 4: 3$, by vol.) as solvent, and an alkaline $\mathrm{AgNO}_{3}$ reagent to detect the sugars.
Protein material was fractionated by molecularsieve chromatography or by ion-exchange chromatography, usually at $0-4^{\circ} \mathrm{C}$. Columns were prepared from the appropriate support materials, by using the manufacturers' instructions, and fractions were collected in a LKB 7000 Ultrorac Fraction Collector (LKB Instruments, Bromma, Sweden). The fractionation of protein solutions was also carried out on the paper curtain of a Beckman Spinco C.P. continuouselectrophoresis cell (Beckman Instruments, Palo Alto, Calif., U.S.A.). Protein solutions were concentrated in Amicon ultrafiltration cells by using Diaflo membranes (Amicon Ltd., High Wycombe, Bucks., U.K.) under a pressure of $380 \mathrm{kPa}\left(55 \mathrm{lbf} / \mathrm{in}^{2}\right)$.

\section{Enzyme assays}

For reductometric assays, appropriate amounts of substrate, buffer ( $0.1 \mathrm{M}$-sodium acetate buffer, $\mathrm{pH} 5.0$, except where otherwise stated) and enzyme were incubated at $37^{\circ} \mathrm{C}$ for a suitable time. Enzyme action was stopped by the addition of Nelson (1944) copper reagent to samples of the digest, and the reducing power was determined. Enzyme digests were usually prepared in duplicate, and appropriate enzyme and substrate controls were also analysed. Suspensions of insoluble laminarin were warmed to $60^{\circ} \mathrm{C}$ before use.

Random hydrolysis of a $\beta$-(1 $\rightarrow 3)$-glucan yields a mixture of glucose and laminarisaccharides. The results are expressed as total reducing power, in glucose equivalents, and not as $\mu \mathrm{mol}$ of substrate hydrolysed or product formed. For the routine assay of column fractions, results are expressed as the increase in extinction at $600 \mathrm{~nm}$ compared with the substrate control, i.e. $\Delta E_{600}$.

Vol. 135 
The following are typical compositions of digests. (a) For the assay of laminarinase activity in continuous-electrophoresis fractions, $0.1 \mathrm{ml}$ of $0.5 \%$ laminarin, $0.4 \mathrm{ml}$ of buffer $(0.01 \mathrm{M}$-sodium acetate, pH 5.0) and $0.5 \mathrm{ml}$ of enzyme solution were incubated for $45 \mathrm{~min}$ and then analysed. For the assay of ionexchange- or molecular-sieve-chromatography fractions, and for the determination of units of $\beta-(1 \rightarrow 3)$ glucanase activity, a standard digest containing $0.5 \mathrm{ml}$ of $1 \%$ laminarin, $0.3-0.4 \mathrm{ml}$ of the acetate buffer and $0.1-0.2 \mathrm{ml}$ of enzyme solution was incubated for $1 \mathrm{~h}$ at $37^{\circ} \mathrm{C}$. Under these conditions, 1 unit of activity is defined as the amount of enzyme that will produce $1 \mu \mathrm{mol}$ of reducing sugar (determined as glucose)/min at $37^{\circ} \mathrm{C}$ and $\mathrm{pH} 5.0$. (b) For laminaribiase activity, $0.5 \mathrm{ml}$ of $0.1 \%$ laminaribiose in the acetate buffer and $0.5 \mathrm{ml}$ of enzyme solution were incubated for $2.5 \mathrm{~h}$. (c) For assay of molecular-sieve-chromatography fractions for barley $\beta$-glucanase activity, $0.5 \mathrm{ml}$ of $0.2 \%$ barley $\beta$-glucan, $0.3 \mathrm{ml}$ of the acetate buffer and $0.2 \mathrm{ml}$ of enzyme fraction were incubated for $4 \mathrm{~h}$ and then analysed. (d) For the assay of ion-exchange chromatography fractions for $\beta$-(1 $\rightarrow 4)$-glucanase activity, $0.5 \mathrm{ml}$ of $1 \% \mathrm{CM}$-cellulose, $0.3 \mathrm{ml}$ of the acetate buffer and $0.2 \mathrm{ml}$ of enzyme fraction were incubated for $1 \mathrm{~h}$ at $37^{\circ} \mathrm{C}$ and then analysed.

For viscometric assays, $1 \mathrm{ml}$ of $1 \%$ substrate [CMpachyman (carboxymethylpachyman), barley $\beta$ glucan or CM-cellulose] and $1 \mathrm{ml}$ of the acetate buffer at $37^{\circ} \mathrm{C}$ were mixed with $0.5 \mathrm{ml}$ of enzyme solution, also at $37^{\circ} \mathrm{C}$. Then $2 \mathrm{ml}$ of the digest was added to a no. 1 B.S.S. Ostwald viscometer in a constanttemperature water bath $\left(37 \pm 0.02^{\circ} \mathrm{C}\right)$. Water had a flow time of $24.0 \mathrm{~s}$. Enzyme activity was expressed as the rate of increase of the reciprocal of specific viscosity with time, $\frac{\mathrm{d}}{\mathrm{d} t}\left(\frac{1}{\eta_{\mathrm{sp}}}\right)$. This relationship was linear with the concentrations of enzyme used.

For the qualitative survey of carbohydrase activity, digests contained $5 \mathrm{mg}$ of substrate and $5 \mathrm{mg}$ of enzyme preparation in $1 \mathrm{ml}$ of the acetate buffer, and were analysed after $24 \mathrm{~h}$ at $37^{\circ} \mathrm{C}$.

The isoamylase (i.e. debranching-enzyme) activity of certain fractions was measured reductometrically by incubating $2 \mathrm{mg}$ of amylopectin $\beta$-limit dextrin with $0.5 \mathrm{ml}$ of the acetate buffer and $0.5 \mathrm{ml}$ of enzyme fraction for $3 \mathrm{~h}$ at $30^{\circ} \mathrm{C}$ (see Gunja-Smith et al., 1970a).

\section{Materials}

The enzyme preparation used was originally obtained from Glaxo Research Ltd., Greenford, Middx., U.K. The preparation is described in British Patent no. 1048887, and was isolated from the culture medium of a micro-organism, which was temporarily designated $\mathrm{L} 1$, and deposited in the National Collection of Industrial Bacteria in
Aberdeen as N.C.I.B. 9497. Although the organism was originally classified as a species of the genus Cytophaga, more recent evidence (Mitchell et al., 1969) suggests that it is in fact a Flavobacterium. Since there is some doubt as to the classification of the bacterium, the genus will not be emphasized in the present paper. The enzyme preparation is now commercially available, as BDH L1 lytic enzyme (BDH Chemicals, Poole, Dorset, U.K.). It is a palecream powder that is dissolved in water, and any insoluble material is removed by centrifugation. There was no significant difference in the specific activity of two samples provided by Glaxo Research Ltd. (0.096 and $0.099 \mathrm{unit} / \mathrm{mg}$ of protein) and a commercial sample ( $0.093 \mathrm{unit} / \mathrm{mg}$ of protein).

The following substrates were laboratory samples available from previous work (e.g. Manners \& Marshall, 1969) on $\beta$-glucans and $\beta$-glucanases: insoluble laminarin, barley $\beta$-glucan, lichenin, luteose, pustulan, cellodextrin, laminarisaccharides ranging in degree of polymerization from 2 to $7,3^{2}$ - $\beta$-glucosylcellobiose, $4^{2}$ - $\beta$-glucosyl-laminaribiose, pachyman and CM-pachyman. CM-cellulose was a commercial sample used previously. The other substrates were laboratory samples of established purity.

\section{Results}

Carbohydrase activity of the bacterial enzyme preparation

Qualitative assays based on paper-chromatographic analysis showed that the following substrates were readily attacked: laminarin, pachyman, yeast glucan, lichenin. Cellodextrin and the disaccharides laminaribiose and cellobiose were slowly hydrolysed. Carbohydrates containing $\beta$-( $1 \rightarrow 6)$-glucosidic linkages (gentiobiose, pustulan, luteose) and a wide range of other possible substrates (maltose, starch, Rhodymenia palmata xylan, Esparto xylan, raffinose, melizitose, sucrose, salicin, methyl $\alpha-$ and $\beta$-Dglucoside and $\beta$-( $1 \rightarrow 4)$-linked $D$-mannose-containing oligosaccharides) were not attacked.

\section{Purification of the bacterial enzyme preparation by continuous-curtain electrophoresis}

The enzyme preparation $(500 \mathrm{mg})$ was dissolved in $10 \mathrm{ml}$ of water and dialysed against running tap water at $2^{\circ} \mathrm{C}$ for $18 \mathrm{~h}$, diluted to $25 \mathrm{ml}$ with distilled water, and the solution clarified by centrifugation. The solution was then applied to the paper curtain of the electrophoresis cell, and the proteins were fractionated in $0.01 \mathrm{M}$-Tris- $\mathrm{HCl}$ buffer, $\mathrm{pH} 7.6$, at $750 \mathrm{~V}$ and $33 \mathrm{~mA}$ at room temperature $\left(22 \pm 3^{\circ} \mathrm{C}\right)$. During electrophoresis the circulating buffer was cooled with ice. The protein content of the fractions was measured from the extinction at $280 \mathrm{~nm}$ and a typical result is show in Fig. 1(a). The distribution of enzyme 
activities is shown in Fig. 1(b). In this experiment, all six racks of tubes showed a similar distribution; in fact, these conditions were highly reproducible for a number of electrophoretic fractionations. The $\beta$ $(1 \rightarrow 3)$-glucanase activity was separated from a large amount of other protein. These fractions were removed from each rack, combined and freezedried, giving $214 \mathrm{mg}$ of freeze-dried enzyme preparation designated CE1. The initial dialysed solution had a specific activity [determined viscometrically against CM-pachyman and expressed as $\frac{\mathrm{d}}{\mathrm{d} t}\left(\frac{1}{\eta_{\mathrm{sp}}}\right) /$ mg of protein] of 0.022. Preparation CE1, which contained only $4 \%$ of the total protein applied to the paper curtain, had a specific activity of 0.333 , representing a 15-fold purification. Continuous electrophoresis in $0.01 \mathrm{M}$-sodium citrate buffer, $\mathrm{pH} 5.2$, did not separate the $\beta-(1 \rightarrow 3)$-glucanase activity from the bulk of the protein.

\section{Properties of preparation CE1}

The effect of $\mathrm{pH}$ on enzyme activity towards laminarin was measured reductometrically. The en-

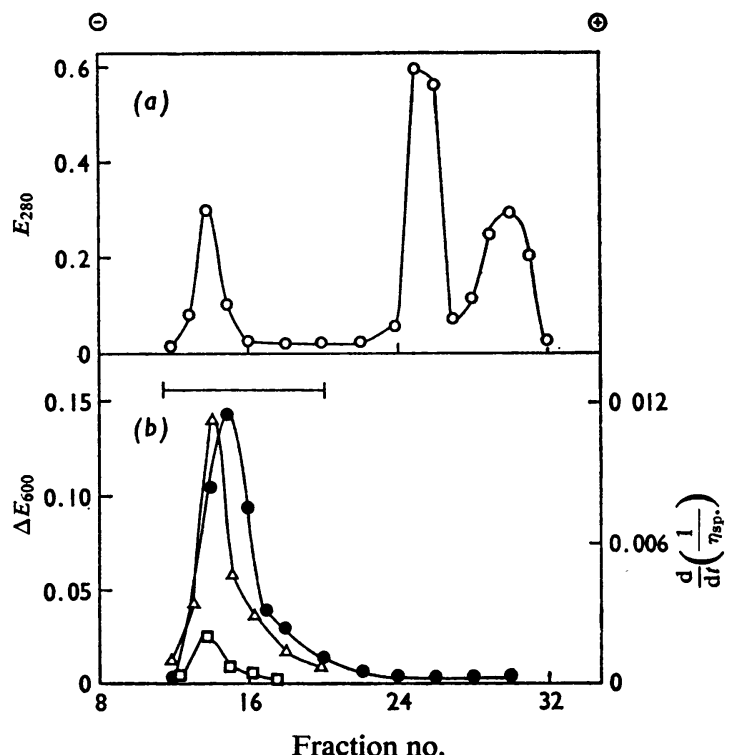

Fig. 1. Continuous electrophoresis of bacterial enzyme preparation

(a) Distribution of protein (O); (b) distribution of enzymic activities. For experimental details see the Methods and Materials section. $\square$, Laminaribiase; -, laminarinase; $\Delta$, activity towards CM-pachyman. The fractions under the horizontal bar were pooled to give preparation CE1. zyme digests contained $0.1 \mathrm{ml}$ of $0.5 \%$ laminarin, $0.4 \mathrm{ml}$ of $0.1 \mathrm{M}$-Tris-acetate buffer (pH range 3.3-9.0) and $0.5 \mathrm{ml}$ of a $0.2 \%$ solution of preparation CEl in water (previously dialysed against water at $2^{\circ} \mathrm{C}$ for $18 \mathrm{~h}$ ), and were incubated at $37^{\circ} \mathrm{C}$ for $40 \mathrm{~min}$. The results (Fig. 2) show a fairly broad pH-activity curve with a maximum at $\mathrm{pH}$ 5.0, and were generally similar to those obtained with a $0.1 \%$ solution of the original enzyme preparation. Further enzyme digests were therefore carried out in $0.1 \mathrm{M}$-sodium acetate buffer, pH5.0.

The specificity of preparation CE1 was examined in digests containing $5 \mathrm{mg}$ of substrate and $1 \mathrm{mg}$ of preparation CE1 in $1 \mathrm{ml}$ of the buffer which were incubated at $37^{\circ} \mathrm{C}$ for $24 \mathrm{~h}$. The enzyme was then inactivated by heating $\left(5 \mathrm{~min}\right.$ at $\left.100^{\circ} \mathrm{C}\right)$, and the solutions were cooled, deionized with Biodeminrolit (The Permutit Co. Ltd., London W.4, U.K.), evaporated to dryness, and then dissolved in $0.1 \mathrm{ml}$ of distilled water for paper-chromatographic analysis. Laminaribiose gave a trace of glucose; CMpachyman and laminarin gave a homologous series of laminarisaccharides ranging in degree of polymerization from 1 to 7; both lichenin and barley glucan gave cellobiose (major product), a trisaccharide, tentatively identified as $3^{2}-\beta$-glucosylcellobiose and a trace of glucose; the xylan from $R$. palmata was not hydrolysed. With laminarin, further experiments showed that a mixture of laminaritriose to laminariheptaose was produced initially (after 3 and $6 \mathrm{~h}$ ) and that glucose and laminaribiose appeared later (after $24 \mathrm{~h}$ ). The results indicate random hydrolysis of $\beta$-(1 $1 \rightarrow 3)$-glucans and of $\beta$-glucans containing both $(1 \rightarrow 3)$ - and $(1 \rightarrow 4)$-linkages.

The relative rates of hydrolysis of $0.25 \%$ solutions of laminarin, lichenin and barley glucan by a $0.1 \%$ solution of preparation CE1 are shown in Fig. 3.

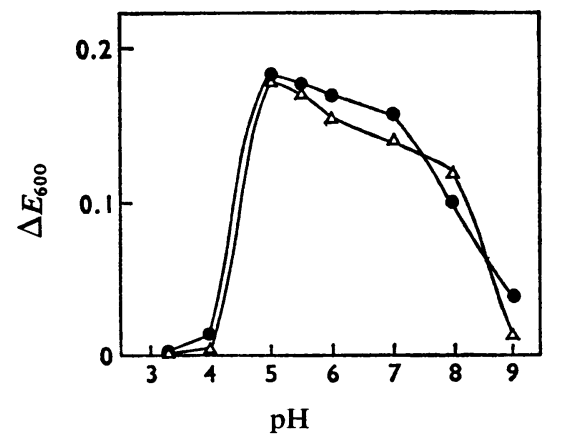

Fig. 2. Effect of $\mathrm{pH}$ on laminarinase activity

Experimental details are given in the text. •, Original bacterial enzyme preparation; $\Delta$, fraction CE1 from continuous electrophoresis. 
The molecular weight of preparation CE1 was determined by molecular-sieve chromatography (Andrews, 1965) by using a column of Sephadex G-100, which had been calibrated with urease (mol.wt. 400000), bovine serum albumin (mol.wt. 67000) peroxidase (mol.wt. 40200), pepsin (mol.wt 35000), $\alpha$-chymotrypsinogen and cytochrome $c$ as reference proteins [supplied by Sigma (London) Chemical Co., London S.W.6, U.K.]. The void volume of the column was $102 \mathrm{ml}$, and the elution volumes of $\alpha$-chymotrypsinogen, laminarinase activity of preparation CE1 and cytochrome $c$ were 189,200 and $213 \mathrm{ml}$ respectively. As the two reference proteins have molecular weights of 25000

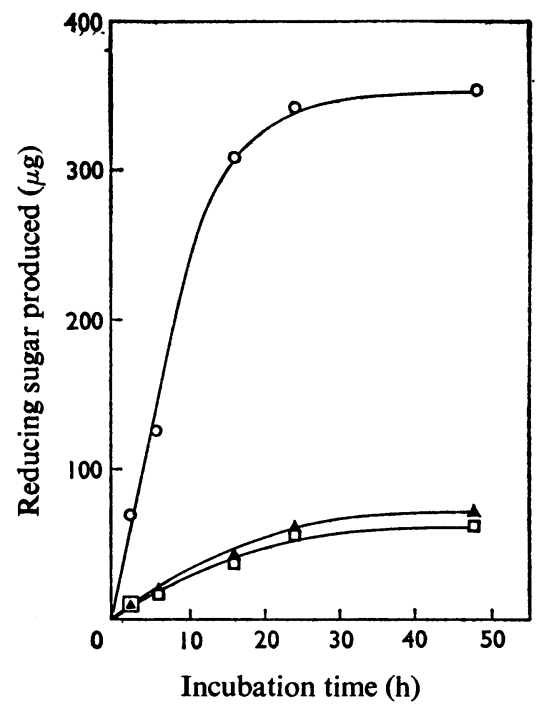

Fig. 3. Rate of hydrolysis of various $\beta$-glucans by enzyme purified by continuous electrophoresis

For details see the text. $\bigcirc$, Laminarin; $\Lambda$, barley $\beta$ glucan; $\square$, lichenin. and 12400 respectively, the results indicate that the $\beta-(1 \rightarrow 3)$-glucanase of preparation CE1 has a molecular weight of about 16600 .

Studies on the ultrafiltration, dialysis and stability of the enzyme preparation

In view of the above molecular-weight determination, the ultrafiltration of the original enzyme preparation was examined, by using a Diaflo PM-10 membrane. The enzyme preparation $(1.0 \mathrm{~g})$ was dissolved in $200 \mathrm{ml}$ of $0.01 \mathrm{M}$-Tris- $\mathrm{HCl}$ buffer, $\mathrm{pH} 7.6$, and the solution clarified by centrifugation. A sample $(1 \mathrm{ml})$ of the clear supernatant solution was retained for analysis, and the remainder concentrated to $50 \mathrm{ml}$ by ultrafiltration at an operating pressure of $380 \mathrm{kPa}\left(55 \mathrm{lbf} / \mathrm{in}^{2}\right)$. The retentate R1 (i.e. material retained by the membrane; volume $50 \mathrm{ml}$ ) and the ultrafiltrate (i.e. material passed through the membrane; volume $150 \mathrm{ml}$ ) were analysed for protein content and $\beta$ - $(1 \rightarrow 3)$-glucanase activity towards laminarin. The results (Table 1) show that about $50 \%$ of the protein passed through the membrane, but that all the enzymic activity was retained.

The results from several experiments have shown that the yield of protein and enzyme obtained from $1 \mathrm{~g}$ of the original enzyme preparation varied between 200 and $280 \mathrm{mg}$ of protein and 15 and 21 units of enzyme activity, and that ultrafiltration resulted in a two- to three-fold increase in specific activity.

Solutions of the enzyme prepared by this method were not very stable on dilution and dialysis. During dialysis against distilled water at $2^{\circ} \mathrm{C}$ for $18 \mathrm{~h}$, about two-thirds of the activity was lost. Although $10 \mathrm{~mm}-$ $\mathrm{Ca}^{2+}$ increased the activity of an undialysed solution by $32 \%$, this concentration of metal ions only partly restored the activity of the dialysed solution. On incubation at $37^{\circ} \mathrm{C}$, the enzyme preparation was partly stabilized by the addition of bovine serum albumin $(500 \mu \mathrm{g} / \mathrm{ml})$ for periods of up to $3 \mathrm{~h}$, but with longer periods $(24-48 \mathrm{~h})$, the protective action was lessened. Further details of these experiments are given elsewhere (Wilson, 1972).

Table 1. Protein and endo- $\beta-(1 \rightarrow 3)-$ glucanase activity in enzyme fractions from ultrafiltration with a PM-10 membrane

For details see the text. Both the endo- $\beta-(1 \rightarrow 3)$ - and endo- $\beta-(1 \rightarrow 4)$-glucanase activities were retained by a PM-30 membrane.

\begin{tabular}{|c|c|c|c|}
\hline Fraction & $\begin{array}{l}\text { Total protein } \\
\text { (mg) }\end{array}$ & $\begin{array}{c}\text { Total } \\
\text { endo- } \beta-(1 \rightarrow 3) \text {-glucanase } \\
\text { activity } \\
\text { (units) }\end{array}$ & $\begin{array}{l}\text { Specific } \\
\text { activity }\end{array}$ \\
\hline Initial extract & 200 & 15.3 & 0.076 \\
\hline Retentate, $\mathrm{R} 1$ & 84 & 14.8 & 0.177 \\
\hline Ultrafiltrate & 75 & 0 & 0 \\
\hline
\end{tabular}


Fractionation of the bacterial enzyme preparation by ion-exchange chromatography

A solution of the enzyme $(1.0 \mathrm{~g}$ in $200 \mathrm{ml}$ of $0.01 \mathrm{M}-\mathrm{Tris}-\mathrm{HCl}$ buffer, $\mathrm{pH}$ 7.6) was clarified and then concentrated to $25 \mathrm{ml}$ by ultrafiltration on a PM-10 membrane. The solution contained $3.6 \mathrm{mg}$ of protein and 0.84 unit of activity $/ \mathrm{ml}$. Part of the solution $(5 \mathrm{ml})$ was applied to a column $(30 \mathrm{~cm} \times 2.5 \mathrm{~cm})$ of DEAE-cellulose, which had been equilibrated with the same buffer. Fractions $(3.2 \mathrm{ml})$ were collected during elution with a linear gradient of $\mathrm{NaCl}(0$ $0.5 \mathrm{M})$ in the Tris $-\mathrm{HCl}$ buffer. The distribution of protein and enzymic activity towards laminarin and amylopectin $\beta$-limit dextrin are shown in Fig. 4.
Assayed against laminarin, fraction 42 had a specific activity of 0.49 unit $/ \mathrm{mg}$ of protein compared with 0.08 and $0.23 \mathrm{unit} / \mathrm{mg}$ of protein for the initial enzyme solution before and after ultrafiltration, indicating a twofold increase in endo- $\beta-(1 \rightarrow 3)$ glucanase activity by DEAE-cellulose chromatography. A second endo- $\beta$-glucanase with activity towards $C M$-cellulose and barley $\beta$-glucan was strongly bound to the anion-exchange resin and was eluted at higher concentrations of $\mathrm{NaCl}(0.5-1.0 \mathrm{M})$. Fig. 5 shows the elution of endo- $\beta$ - $(1 \rightarrow 3)$-glucanase and endo- $\beta$ - $(1 \rightarrow 4)$-glucanase activities by a gradient of $\mathrm{NaCl}(0-1 \mathrm{M})$ in Tris- $\mathrm{HCl}$ buffer, followed by further elution with $1 \mathrm{M}-\mathrm{NaCl}$.

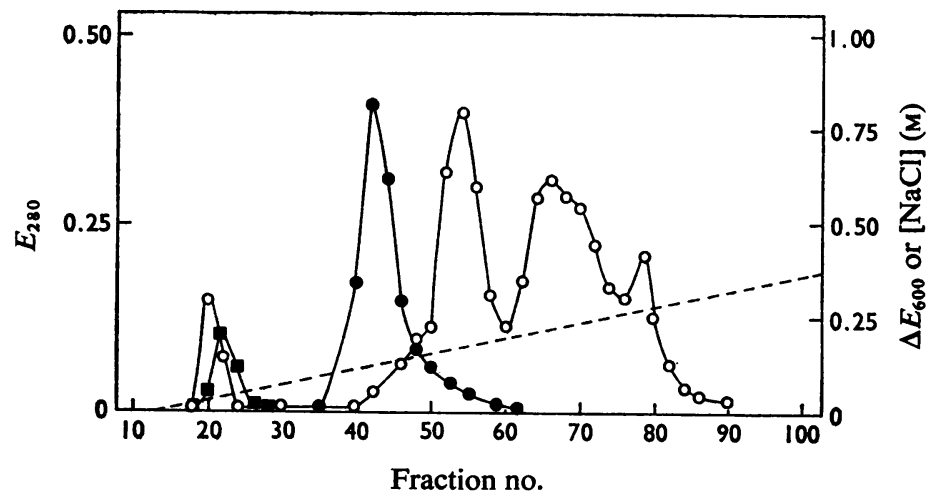

Fig. 4. DEAE-cellulose chromatography of bacterial enzyme preparation at low salt concentrations

Fractions of $3.2 \mathrm{ml}$ were collected. For other details see the text. $\bigcirc$, Protein; $\bullet$, laminarinase activity; $\square$, isoamylase activity; ----, [NaCl].

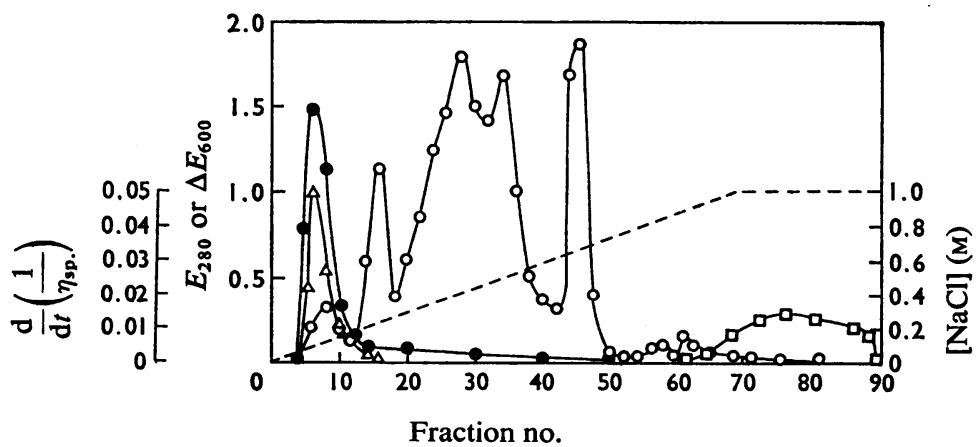

Fig. 5. DEAE-cellulose chromatography of bacterial enzyme preparation at high salt concentrations

Fractions of $3.5 \mathrm{ml}$ were collected. For other details see the text. $\bigcirc$, Protein; $\bullet$, laminarinase activity; $\Delta$, activity towards CM-pachyman; $\square$, activity towards CM-cellulose; ----, [NaCl]. 
Fractions from a DEAE-cellulose column, containing endo- $\beta-(1 \rightarrow 3)$-glucanase activity, were concentrated by ultrafiltration and applied to the calibrated column of Sephadex G-100. The endo- $\beta$ $(1 \rightarrow 3)$-glucanase activity was eluted after $204 \mathrm{ml}$, equivalent to a molecular weight of about 15000 . The endo- $\beta$ - $(1 \rightarrow 4)$-glucanase activity was not retained by a PM-10 membrane (suggesting a molecular weight of less than 10000), but was concentrated on a UM-2 membrane. It is noteworthy that the isoamylase activity, which has a molecular weight of about 120000 (Gunja-Smith et al., 1970a), was not firmly bound to the DEAE-cellulose at pH7.6.

The specificity of the two $\beta$-glucanases was examined by incubating $0.1 \mathrm{ml}$ of the concentrated enzyme solutions with $2 \mathrm{mg}$ of substrate in $0.1 \mathrm{ml}$ of the acetate buffer for $24 \mathrm{~h}$ at $37^{\circ} \mathrm{C}$. Paper-chromatographic analysis showed that the endo- $\beta-(1 \rightarrow 3)$ glucanase hydrolysed laminarin and CM-pachyman, yielding glucose and oligomers, but did not attack barley $\beta$-glucan or cellodextrin. The endo- $\beta-(1 \rightarrow 4)-$ glucanase attacked cellodextrin to produce cellobiose, cellotriose and higher oligosaccharides. This enzyme also hydrolysed barley $\beta$-glucan and lichenin, yielding a trisaccharide as the major product together with oligosaccharides of higher degree of polymerization. The trisaccharide was tentatively identified as $3^{2}-\beta$-glucosylcellobiose by its paper-chromatographic mobility and its paper-electrophoretic mobility in $0.05 \mathrm{M}$-sodium borate buffer, $\mathrm{pH} 10.0$, at a potential of $10 \mathrm{~V} / \mathrm{cm}$ for $1 \mathrm{~h}$. The mobilities were different from those of $4^{2}-\beta$-glucosyllaminaribiose.

\section{Fractionation of the bacterial enzyme preparation by molecular-sieve chromatography}

A solution containing $12.0 \mathrm{mg}$ of protein and 2.30 units of endo- $\beta-(1 \rightarrow 3)$-glucanase activity/ml was prepared by ultrafiltration on a PM-10 membrane. A $3 \mathrm{ml}$ sample was applied to a column $(60 \mathrm{~cm} \times$ $2.5 \mathrm{~cm}$ ) of Bio-Gel P-60, which had been equilibrated with $0.01 \mathrm{M}$-acetate buffer, pH5.0. The column was eluted at $2 \pm 2^{\circ} \mathrm{C}$ with the buffer, at a flow rate of $5 \mathrm{ml} / \mathrm{h}$, fractions of $3.5 \mathrm{ml}$ being collected. The distribution of protein in the fractions and enzymic activity towards laminarin, barley $\beta$-glucan and CM-cellulose is shown in Fig. 6. The results show two peaks of $\beta$-glucanase activity that are partially separated from each other. Since these peaks are eluted near the void volume of the column, this suggests that their molecular weights approach 60000 , which is the exclusion limit of Bio-Gel P-60. Assayed against laminarin, fraction 25 had a specific activity of 0.435 unit $/ \mathrm{mg}$ of protein compared with 0.07 and 0.20 for the initial enzyme solution before and after ultrafiltration. When incubated with $12.5 \mathrm{~mm}-\mathrm{Ca}^{2+}$ or $2.0 \mathrm{~mm}$-EDTA, the activity of fraction 25 was increased by $32 \%$ or decreased by $16 \%$ respectively.

Fractionation of $L 1$ enzyme solutions on Bio-Gel P-60 under these conditions gave highly reproducible results. It was observed, however, that different experimental conditions produced elution patterns that differed from those shown in Fig. 6. For example, when molecular-sieve chromatography was performed at room temperature $\left(22 \pm 3^{\circ} \mathrm{C}\right)$, low-molecularweight forms of $\beta-(1 \rightarrow 4)$-glucanase were obtained. Fig. 7 shows the results from such an experiment in which all the $\beta-(1 \rightarrow 4)$-glucanase activity was obtained in a low-molecular-weight form, resulting in a complete separation of the activities towards laminarin and CM-cellulose. Fractions containing enzyme activity were combined and concentrated by ultrafiltration. A portion $(0.1 \mathrm{ml})$ of each enzyme solution was incubated at $37^{\circ} \mathrm{C}$ for $24 \mathrm{~h}$ with $0.1 \mathrm{ml}$ of a $1 \%$ solution of laminarin or a $0.5 \%$ solution of barley

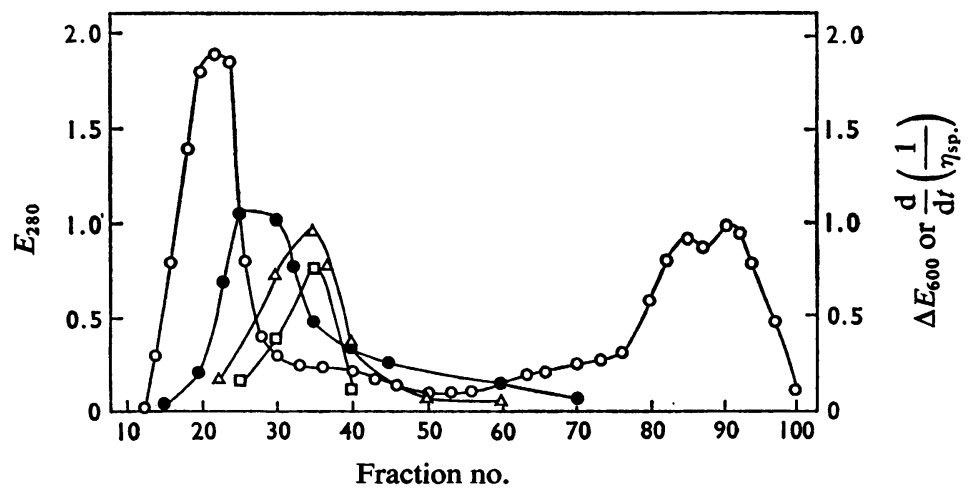

Fig. 6. Fractionation of bacterial enzyme preparation on Bio-Gel P-60 at $2^{\circ} \mathrm{C}$

Fractions of $3.5 \mathrm{ml}$ were collected. For other details see the text. $\bigcirc$, Protein; $\bullet$, laminarinase; $\square$, activity towards CM-cellulose; $\Delta$, activity towards barley $\beta$-glucan. 


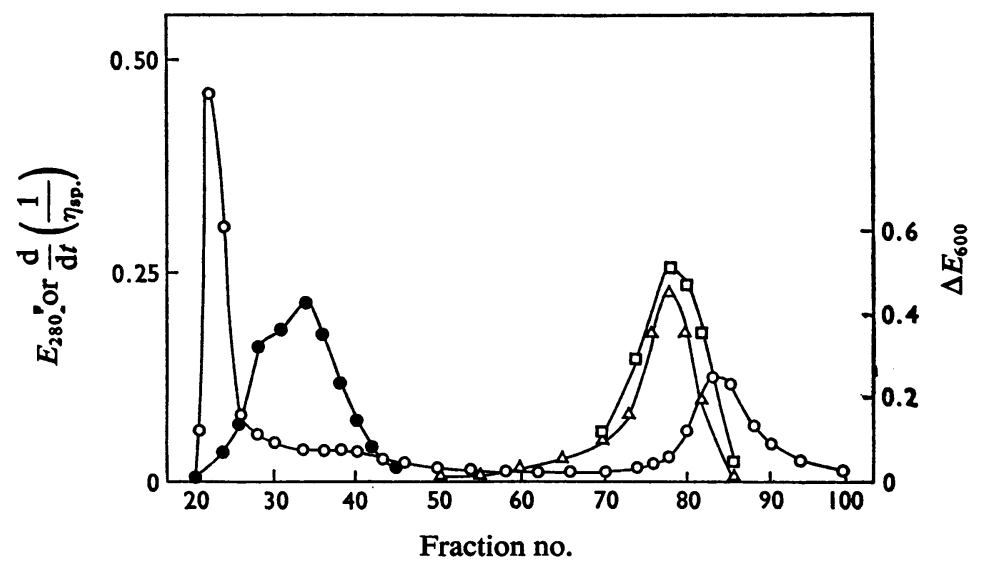

Fig. 7. Fractionation of bacterial enzyme preparation on Bio-Gel P-60 at $25^{\circ} \mathrm{C}$

Fractions of $3.5 \mathrm{ml}$ were collected. For other details see the text. $\bigcirc$, Protein; $\bullet$, laminarinase; $\square$, activity towards CM-cellulose; $\Delta$, activity towards barley $\beta$-glucan.

$\beta$-glucan. Paper-chromatographic analysis showed that the $\beta-(1 \rightarrow 3)$-glucanase fraction had no activity towards cellodextrin or barley $\beta$-glucan, but caused random hydrolysis of laminarin. It also caused a significant decrease in the viscosity of solutions of CM-pachyman. By contrast, the $\beta-(1 \rightarrow 4)$-glucanase had no action on laminarin, but hydrolysed barley $\beta$-glucan giving $3^{2}-\beta$-glucosylcellobiose as the major product together with traces of higher oligosaccharides. With cellodextrin it produced cellobiose, cellotriose and higher oligosaccharides.

Molecular-sieve chromatography was also carried out at $22 \pm 3^{\circ} \mathrm{C}$ on Sephadex G-200 as the chromatographic support. Fractionation of enzyme solutions that had been prepared in $0.01 \mathrm{M}$-Tris- $\mathrm{HCl}$ buffer, pH 7.6 (the same enzyme solution was used for ionexchange chromatography), yielded both high- and low-molecular-weight forms of $\beta-(1 \rightarrow 3)$-glucanase and $\beta-(1 \rightarrow 4)$-glucanase activity.

The stability of the purified $\beta-(1 \rightarrow 4)$-glucanase at $37^{\circ} \mathrm{C}$ was examined. After $0,30,60$ and $180 \mathrm{~min}$ at $37^{\circ} \mathrm{C}$ the relative activity of the enzyme towards barley $\beta$-glucan was $45,26,20$ and 0 respectively (expressed as $\mu \mathrm{g}$ of reducing sugar per digest). This activity was therefore unstable at $37^{\circ} \mathrm{C}$ in the absence of substrate, and there was a complete loss of activity within $3 \mathrm{~h}$.

\section{Discussion}

The original patent description of the bacterial enzyme preparation mentioned a number of hydrolytic activities, including laminarinase, chitinase and keratinase. The preparation also contains a powerful starch-debranching enzyme, isoamylase (Gunja-
Smith et al., 1970a), which is proving to be a useful enzyme for the structural analysis of starch and glycogen-type polysaccharides (see, e.g., GunjaSmith et al., 1970b; R. Gordon, D. J. Manners, J. R. Stark \& D. Yellowlees, unpublished work).

The present investigation has shown that the bacterial enzyme preparation contained a mixture of $\beta$-glucanases, accompanied by weak laminaribiase activity. The results from molecular-sieve and ionexchange chromatography indicate that laminarin and barley $\beta$-glucan or cellodextrin were hydrolysed by specific enzymes, an endo- $\beta-(1 \rightarrow 3)$-glucanase and an endo- $\beta-(1 \rightarrow 4)$-glucanase. Continuous electrophoresis at $\mathrm{pH} 7.6$ failed to separate these activities. However, they were separated on columns of Bio-Gel P-60 (Fig. 7) and on DEAE-cellulose (Fig. 5). Endo$\beta$-(1 14$)$-glucanase activity in a BDH bacterial enzyme preparation has been reported independently by Marshall (1972), who also used DEAEcellulose chromatography to fractionate the preparation.

Both of the enzymes appeared to exist in high- and low-molecular-weight forms. In unfractionated solutions both activities were retained by Amicon PM30 membranes and therefore presumably had molecular weights in excess of 30000 . By contrast, during molecular-sieve chromatography at $25^{\circ} \mathrm{C}$ on Bio-Gel P-60 the endo- $\beta-(1 \rightarrow 3)$-glucanase activity was eluted near the void volume (molecular weight approaching $60000)$, and the endo- $\beta$ - $(1 \rightarrow 4)$-glucanase activity was observed as a low-molecular-weight form (Fig. 7). Both the endo- $\beta-(1 \rightarrow 3)$-glucanase and endo- $\beta-(1 \rightarrow 4)-$ glucanase were obtained as low-molecular-weight enzymes from DEAE-cellulose or continuous electrophoresis. The endo- $\beta$ - $(1 \rightarrow 3)$-glucanase had a 
molecular weight of about 16000 (from DEAEcellulose and continuous electrophoresis).

It would be premature at the present time to consider these changes in terms of monomer $\rightleftharpoons$ trimer or tetramer interconversions, although this clearly represents one possibility. However, the original patent for the enzyme preparation reports the presence of proteolytic activity (pH optimum 8 and temperature optimum $37^{\circ} \mathrm{C}$ ), and in further experiments on ion-exchange chromatography, we have found that those fractions containing endo- $\beta-(1 \rightarrow 3)$ glucanase activity also show hydrolytic activity towards casein (D. J. Manners \& G. Wilson, unpublished work). This latter activity is only partially decreased by protease inhibitors such as methylphenylsulphonyl fluoride. It is therefore possible that proteolytic digestion may play some part in the conversion of high-molecular-weight forms into smaller molecules. This type of digestion has been observed with pullulanase from Aerobacter aerogenes, where partial proteolytic degradation may occur during isolation and storage of the debranching enzyme (Eisele et al., 1972).

The major purpose of this work was to examine the suitability of the bacterial enzyme preparation for structural studies on $\beta$-glucans. Without purification, it may be used for the degradation of simple $\beta-(1 \rightarrow 3)$ glucans, such as callose. Since the preparation has no action on $\beta-(1 \rightarrow 6)$-glucosidic linkages in oligosaccharides, e.g. gentiobiose and $6^{2}-\beta$-glucosyllaminaribiose (Fleming et al., 1967), or in polysaccharides, e.g. luteose and pustulan, it may be used with caution for the structural analysis of glucans containing both $\beta$-(1 $1 \rightarrow 3)$ - and $\beta-(1 \rightarrow 6)$-linkages. This use may be illustrated by studies on yeast glucan (Manners \& Patterson, 1966) and in the preparation of protoplasts from yeasts (Baird \& Cunningham, 1971; San Blas, 1972). In the present work, linear $\beta$-glucans containing both $(1 \rightarrow 3)$ - and $(1 \rightarrow 4)$-linkages, e.g. lichenin and barley $\beta$-glucan, were hydrolysed by the endo- $\beta$ - $(1 \rightarrow 4)$-glucanase, and not by the endo- $\beta$ $(1 \rightarrow 3)$-glucanase. For this latter enzyme, long sequences of adjacent $\beta$-(1 $\rightarrow 3)$-linked glucose residues appear to be required in the substrate.

In general terms, the $\beta$-glucanases are not very stable, and there is loss of activity during continuous electrophoresis and chromatography. This may be partly owing to proteolysis, and partly to a requirement for $\mathrm{Ca}^{2+}$ or other metal ions, although the present results do not lead to the conclusion that the endo- $\beta$ - $(1 \rightarrow 3)$-glucanase is a calcium metalloprotein, resembling $\alpha$-amylase (see Robyt \& Whelan, 1968). Since enzymic activity is diminished during incubation at $37^{\circ} \mathrm{C}$ (that of the low-molecular-weight form of the $\beta$ - $(1 \rightarrow 4)$-glucanase being decreased to 44 and $0 \%$ after 1 and $3 \mathrm{~h}$ respectively), by dilution and by dialysis, any experimental conditions must ensure that an excess of active enzyme is always present. However, since the original enzyme preparation contains a significant amount of non-protein material, including galactomannan (D. J. Manners \& J. C. Patterson, unpublished work), there is a danger that the products of $\beta$-glucan degradation could be contaminated with other carbohydrate material, unless some method of purification is used. The instability of the $\beta$-glucanases is similar to that reported for the isoamylase activity of this bacterial preparation (Gunja-Smith et al., 1970a); in the absence of substrate, almost all this activity was lost within $1 \mathrm{~h}$ at $40^{\circ} \mathrm{C}$. Nevertheless, in spite of these limitations, the bacterial $\beta$-glucanase system represents a convenient source of enzyme for the structural analysis of $\beta$-glucans.

We are indebted to Glaxo Research Ltd. for supplying the bacterial enzyme preparation, to Dr. W. F. J. Cuthbertson for his interest in this work, to Dr. J. C. Patterson and Dr. D. C. Taylor for their collaboration during the initial stages of these researches, and to the Science Research Council for the award of a research studentship (to G. W.).

\section{References}

Andrews, P. (1965) Biochem. J. 96, 595-606

Baird, J. K. \& Cunningham, W. L. (1971) Biochem. J. 125, 32P-33P

Eisele, B., Rasched, I. R. \& Wallenfels, K. (1972) Eur. J. Biochem. 26, 62-67

Fleming, M., Manners, D. J. \& Masson, A. J. (1967) Biochem. J. 104, 32 P-33P

Gunja-Smith, Z. H., Marshall, J. J., Smith, E. E. \& Whelan, W. J. (1970a) FEBS Lett. 12, 96-100

Gunja-Smith, Z. H., Marshall, J. J., Mercier, C., Smith, E. E. \& Whelan, W. J. (1970b) FEBS Lett. 12, 101-104

Manners, D. J. \& Marshall, J. J. (1969) J. Inst. Brew. 75, 550-561

Manners, D. J. \& Patterson, J. C. (1966) Biochem. J. 98, 19c-20c

Manners, D. J. \& Wilson, G. (1972) Abstr. International Carbohydrate Conference 6th, Madison, pp. 17-18

Marshall, J. J. (1972) J. Chromatogr. 71, 367-369

Miller, G. L. (1959) Anal. Chem. 31, 964

Mitchell, T. G., Hendrie, M. S. \& Shewan, J. M. (1969) J. Appl. Bacteriol. 32, 40-50

Nelson, N. (1944) J. Biol. Chem. 153, 375-380

Robyt, J. F. \& Whelan, W. J. (1968) in Starch and its Derivatives (Radley, J. H., ed.), 4th edn., pp. 430-476, Chapman and Hall, London

San Blas, G. (1972) Ph.D. Thesis, Heriot-Watt University

Somogyi, M. (1945) J. Biol. Chem. 160, 61-68

Somogyi, M. (1952) J. Biol. Chem. 195, 19-23

Wilson, G. (1972) Ph.D. Thesis, Heriot-Watt University 